\title{
SAGEMAP: A Web-based Spatial Dataset for Sage Grouse and Sagebrush Steppe Management in the Intermountain West
}

\section{Abstract}

The Snake River Field Station of the Forest and Rangeland Ecosystem Science Center has developed and now maintains a database of the spatial information needed to address management of sage grouse and sagebrush steppe habitats in the western United States. The SAGEMAP project identifies and collects information for the region encompassing the historical extent of sage grouse distribution. State and federal agencies, the primary entities responsible for managing sage grouse and their habitats, need the information to develop an objective assessment of the current status of sage grouse populations and their habitats, or to provide responses and recommendations for recovery if sage grouse are listed as a Threatened or Endangered Species.

The spatial data on the SAGEMAP website (http://SAGEMAP.wr.usgs.gov) are an important component in documenting current habitat and other environmental conditions. In addition, the data can be used to identify areas that have undergone significant changes in land cover and to determine underlying causes. As such, the database permits an analysis for large-scale and range-wide factors that may be causing declines of sage grouse populations. The spatial data contained on this site also will be a critical component guiding the decision processes for restoration of habitats in the Great Basin. Therefore, development of this database and the capability to disseminate the information carries multiple benefits for land and wildlife management.

\section{Sagebrush Steppe Ecosystems}

Many birds and mammals depend on sagebrush ecosystems in the western United States for survival. Plants and animals that can survive only in communities dominated by sagebrush are called sagebrushobligate species. Sage grouse, which are a highly visible and distinguished bird, are one such obligate species associated with sagebrush. In the last century, drastic changes caused by livestock grazing, conversion of lands to agriculture, the introduction of exotic plant species, and fire have resulted in alteration of the vegetation community or caused extensive fragmentation and loss of shrublands throughout the

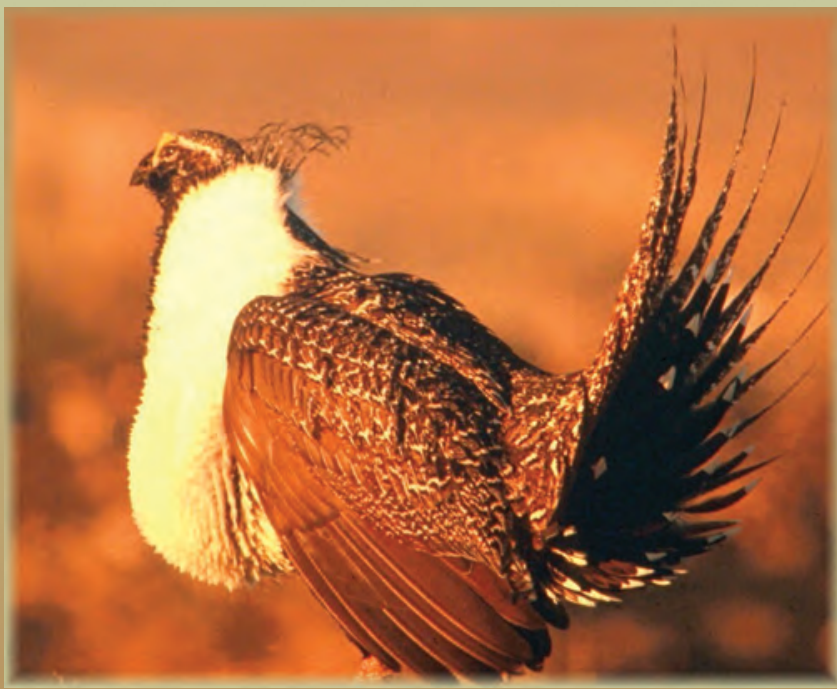

Greater sage-grouse (Centrocercus urophasianus) are used as an indicator of what will happen to many other species of wildlife in sagebrush ecosystems.

Intermountain West. Such changes in local vegetation communities and the loss of sagebrush ecosystems from the landscape are negatively affecting many of the more than 350 species of plants and animals that depend on sagebrush ecosystems for all or part of their existence.

Despite long-term research and conservation efforts, sage grouse populations have declined throughout much of the Intermountain West and now are absent from many parts of their historical range. The negative impacts from loss of sagebrush habitat on sage grouse are indicative of what will happen to many other species of wildlife in these shrublands. According to Steve Knick, a research ecologist at the 
Forest and Rangeland Ecosystem Science Center, "Sage grouse are being used as the poster species and as an indicator of fragmentation and loss of sagebrush ecosystems. The coupling of disturbance, invasion by exotic plant species, and human activities have changed the native vegetation communities and altered the form and function of these systems in such a way that sage grouse cannot exist as they once did." Conservation of sagebrush steppe ecosystems will not only benefit sage grouse but also a variety of other birds, big-game species, and smaller animals such as the pygmy rabbit (Brachylagus idahoensis) and sagebrush lizard (Sceloporus graciosus).

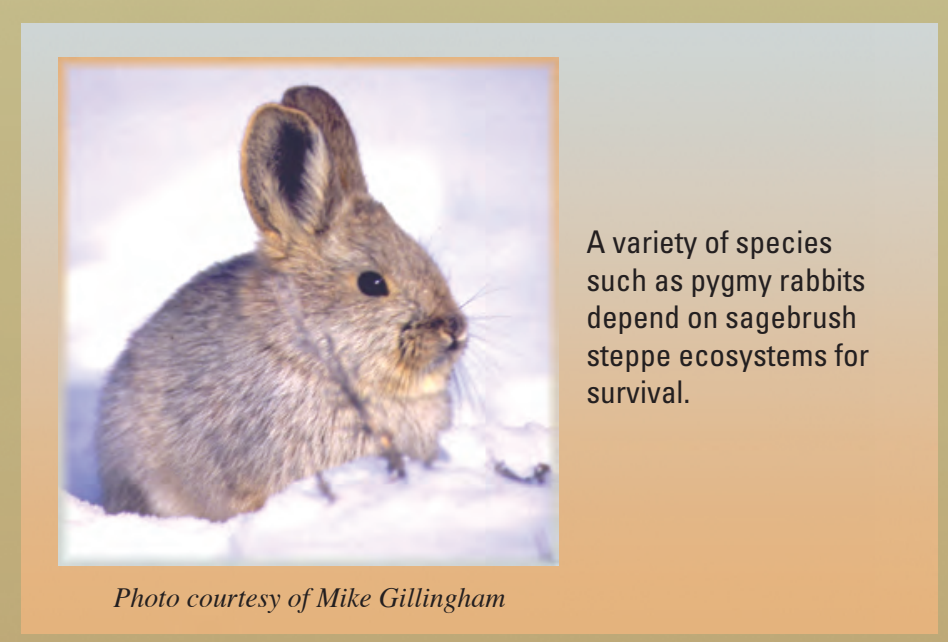

\section{Using Spatial Data}

Most of the remaining sagebrush lands in the western United States are public lands managed by federal or state agencies. Spatial data can play a critical role in issues such as the assessment process for listing of greater sage-grouse as a Threatened or Endangered Species or to help guide decisions on restoration of habitat in the Great Basin. Research and analysis of these and other management issues for sagebrush regions in the western United States have been difficult because existing spatial data were limited in the extent of their coverage or were inconsistent across ecological or administrative boundaries. In addition, many datasets were not accessible because of computer software or hardware incompatibility, or were not available in digital format. Therefore, identifying, collecting, documenting, and making common datasets readily available on a web-based site were important components in the SAGEMAP project.

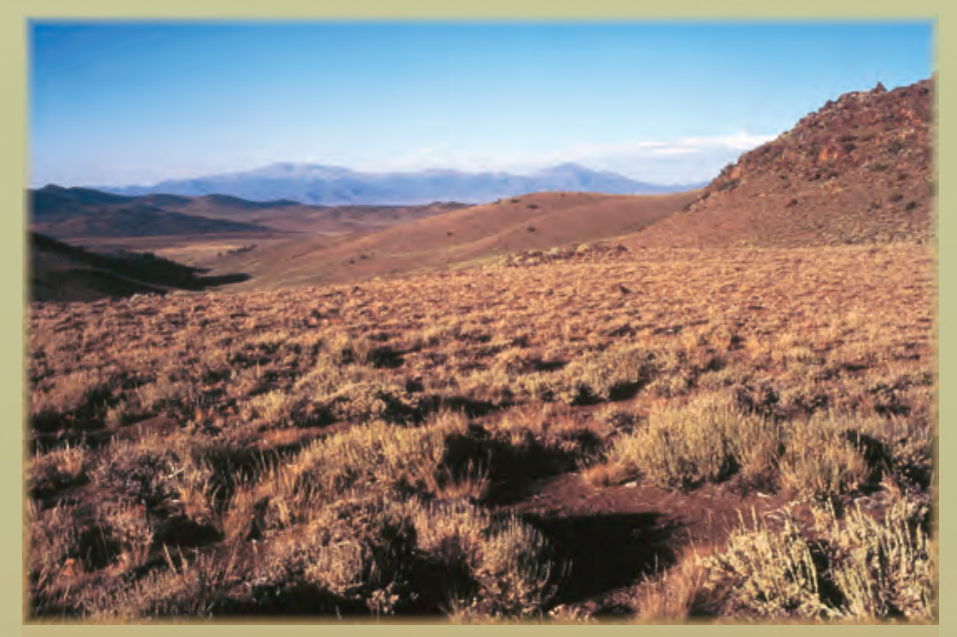

Sagebrush steppe landscape. The loss of this ecosystem is having a serious impact on many wildlife species.

\section{SAGEMAP Website}

The website developed on the SAGEMAP project (http://SAGEMAP.wr.usgs.gov) is regularly updated, and new datasets are added continually. The list of datasets available on the site can be queried and viewed, and any dataset can be downloaded without charge. Each dataset has an associated metadata record that documents the source, attributes, and development information for the data. In addition to the spatial data layers, the web site also includes a list of contacts for spatial data, a form to request specific data layers that may not be on the site, a ListServ for sage grouse and sagebrush issues, and a list of upcoming meetings. In addition, documents important for managing sage grouse and shrubsteppe habitats, such as the "Guidelines to manage sage grouse populations and their habitats" (Connelly et. al. 2000. Wildlife Society Bulletin), can be downloaded from the site. The SAGEMAP project conducted at the Snake River Field Station is playing a critical role in collecting and disseminating the information needed for research and management of shrubsteppe habitats and associated wildlife in the Intermountain West.

\section{Contact:}

Steven T. Knick, USGS Forest and Rangeland

Ecosystem Science Center, Snake River Field Station, 970 Lusk Street, Boise, ID 83706 (ph: 208-426-5208; email: steve_knick@usgs.gov)

Linda Schueck, USGS Forest and Rangeland Ecosystem Science Center, Snake River Field Station, 970 Lusk Street, Boise, ID 83706 (ph: 208-426-3353; email: 1schueck@usgs.gov) 